\title{
Meiotic Chromosome Behaviours of Auto-pentaploid Rice Plant Derived from Anther Culture
}

\author{
Yoshio Watanabe \\ Division of Genetics, Department of Physiology and Genetics, National Institute \\ of Agricultural Sciences, Hiratsuka, Kanagawa, 254 Japan
}

Received October 10, 1972

In cultivated rice, Oryza sativa L. $(2 \mathrm{n}=24, \mathrm{AA})$, a number of reports on haploids $(2 n=12, A)$, triploids $(2 n=36$, AAA $)$, and tetraploids $(2 n=48$, AAAA) have been published so far. No pentaploid $(2 n=60$, AAAAA), however, has been reported up to date.

Nishi and Mitsuoka (1969) have first succeeded to induce a series of polyploids from haploid to pentaploid in rice through its tissue culture. The present author was kindly furnished one stubble of pentaploid rice plants from them, and was able to observe its meiotic chromosome behaviours. This paper deals briefly with its meiotic chromosome behaviours as well as its morphological features.

\section{Material and methods}

Nishi and Mitsuoka (1969) have raised seven pentaploid rice plants through anther culture using a cultivar, "Kyoto-Asahi". One of these as designated A4 was vegetatively multiplied, and subjected to cytogenetic observations.

Root-tip cells were fixed with 1:3 acetic-alcohol for one day, mordanted with $4.0 \%$ iron-alum solution for 2 hours after maceration with $1 \mathrm{~N} \mathrm{HCl}$ for 7 minutes, and stained with aceto-carmine solution for more than 3 hours. PMCs were fixed and mordanted at the same time with 1:3 acetic-alcohol containing $0.5 \%$ ferric chloride, and stored in the refrigirator until used. For cytological observations, squashed preparations were made by staining with aceto-carmine solution.

\section{Results}

In root-tip cells, 60 chromosomes were invariably observed, showing that this plant is auto-pentaploid (Fig. 1). In PMCs, however, a number of aneuploid cells were observed ranging from 33 to 99 in 2 n numbers when reckoned from the chromosome configurations in MI (Table 1, Fig. 2). Only 3 cells were observed possessing 60 chromosomes which was equal to the somatic number in RTCs. Their chromosome configurations were $2_{\text {IV }}+26_{\text {II }}, 4_{\text {IV }}+22_{\text {I I }}$, and $2_{\text {I I I }}+26_{\text {I I }}+2_{\text {I }}$, respectively. Strictly speaking, this plant should be called mixoploid, and multivalents such as trivalents or tetravalents were frequently formed in most PMCs. In one cell, 4 pentavalents were met with. Univalents also were frequently observed ranging from 1 to 10 .

Out of 30 PMCs examined, 4 cells possessed 56 chromosomes which was the 

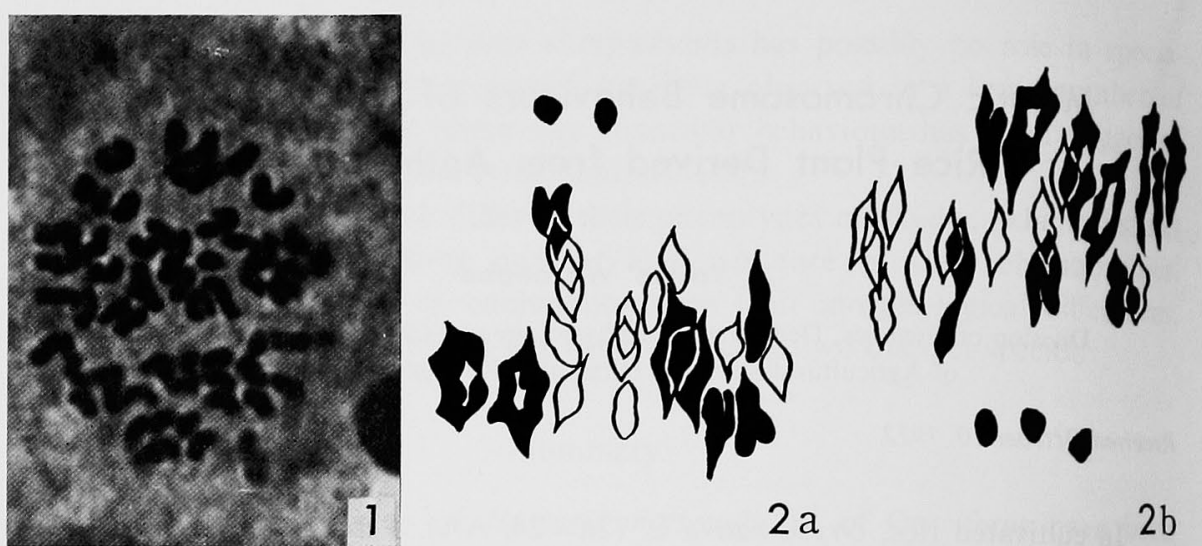

Figs. 1-2. 1, somatic chromosomes in MI of $5 X$ plant $(2 n=60) . \quad 2$, drawings of 1st metaphasic plates showing (a) $4_{I V}+4_{I I I}+11_{I I}+2_{I}(2 n=52)$ and (b) $3_{I V}+7_{I I I}+10_{I I}+3_{I}(2 n=56)$.

Table 1. Chromosome-mosaicism observed in PMCs of pentaploid rice plant

\begin{tabular}{|c|c|c|}
\hline $2 n$ & chromosome configuration & frequency \\
\hline 33 & $2{ }_{I V}+11_{I I}+3 I$ & 1 \\
\hline 38 & $1_{I V}+6_{I I I}+8_{I I}$ & 1 \\
\hline 39 & $55_{I I I}+12_{I I}$ & 1 \\
\hline 40 & $1_{I V}+16_{I I}+4 I$ & 1 \\
\hline 41 & $20_{I I}+1_{I}$ & 1 \\
\hline 42 & $\begin{array}{l}6 \text { III }+10_{I I}+44_{I} \\
3_{I V}+88_{I I I}+22_{I I}+2 I\end{array}$ & $\left.\begin{array}{l}1 \\
1\end{array}\right\} 2$ \\
\hline 44 & $1_{I V}+1_{I I I}+17_{I I}+3_{I}$ & 1 \\
\hline 45 & $1_{I V}+9_{I I I}+7_{I I}$ & 1 \\
\hline 46 & $22_{I I}+2{ }_{I}$ & 1 \\
\hline 47 & $2_{I V}+19_{I I I}+1_{I}$ & 1 \\
\hline 49 & $22_{I I}+5$ I & 1 \\
\hline 50 & $3_{I I I}+18_{I I}+5_{I}$ & 1 \\
\hline 51 & $\begin{array}{l}4 \mathrm{III}+18_{I I}+3_{I} \\
1_{I V}+23_{I I}+1_{I}\end{array}$ & $\left.\begin{array}{l}1 \\
1\end{array}\right\} 2$ \\
\hline 52 & $\begin{array}{l}24_{I I}+44_{I} \\
4_{I V}+44_{I I I}+11_{I I}+2{ }_{I} \\
1_{V}+2{ }_{I V}+1_{I I I}+16{ }_{I I}+4 I\end{array}$ & $\left.\begin{array}{l}1 \\
1 \\
1\end{array}\right\} 3$ \\
\hline 55 & $\begin{array}{l}5_{I V}+1_{I I I}+16_{I I} \\
1_{V}+3_{I V}+7 \text { III }+8 I I+1_{I I}\end{array}$ & $1\}^{2}$ \\
\hline 56 & $\begin{array}{l}28_{I I} \\
1_{I V}+2 I I I+18_{I I}+10_{I} \\
3_{I V}+7_{I I I}+10_{I I}+3_{I I} \\
4 V+3 I V+5 I I I \\
4 V+4 I I\end{array}$ & $\left.\begin{array}{l}1 \\
1 \\
1 \\
1\end{array}\right\} 4$ \\
\hline 57 & $\begin{array}{l}5_{I V}+1_{I I I}+16 \text { II }+2 \text { II } \\
7_{I V}+1_{I I I}+11_{I I}+44_{I}\end{array}$ & $\left.\begin{array}{l}1 \\
1\end{array}\right\} 2$ \\
\hline 60 & $\begin{array}{l}2 I_{I I I}+26_{I I}+2 I \\
2_{I V}+26_{I I} \\
4 I V+22_{I I}\end{array}$ & $\left.\begin{array}{l}1 \\
1 \\
1\end{array}\right\}^{3}$ \\
\hline 99 & $1 \mathrm{~V}+3_{I V}+8_{I I I}+24_{I I}+10_{I}$ & 1 \\
\hline \multicolumn{2}{|r|}{ Total } & 30 \\
\hline
\end{tabular}


modal number of these aneuploid cells, though their chromosome configurations were different in different cells. It is interesting to note that out of these 4 cells, 2 showed the extreme configurations, one the most regular pairing of $28_{I I}$, the other the most irregular pairing of $4_{V}+3_{I V}+5_{I I I}+4_{I I}+1_{I}$, respectively. As a result of such meiotic irregularities, the pentaploid plant showed low pollen fertility of $8.5 \%$. Even these pollen grains stained red with aceto-carmine did not seem to possess the functioning ability.

This plant showed anthesis similar to cleistogamy, but fertilization has never taken place, being characterized by extreme parthenocarpy. The number of anthers

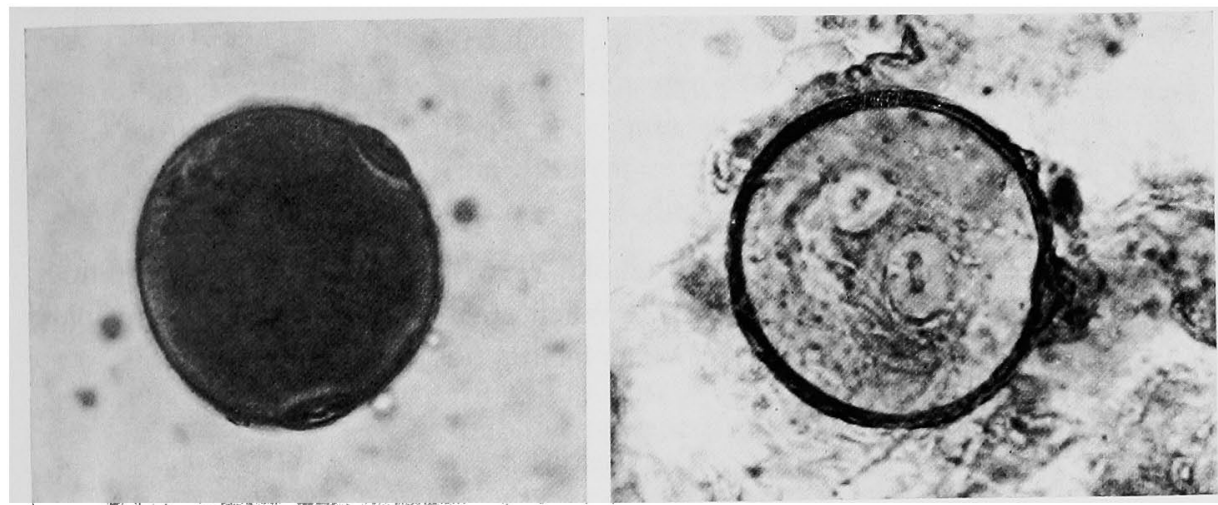

Fig. 3. Pollen grains with 2 germ-pores.

in a floret varied from 3 to 6 , the mode being 6 , though 1 to 5 of them showed rudimentary development (Table 2). The most conspicuous feature of this plant was the formation of multi-germ-pores on pollen grains, which has never been found in rice. That is to say, the pollen grains with 2 to 4 germ-pores were frequently observed in addition to the normal grains with one germ-pore. The modal number of germ-pores observed was 2 (Table 3, Fig. 3).

Morphologically, pentaploid rice plant showed similar grass type to that of tetraploid in having coarser and thicker leaves, longer panicles, larger spikelets with awns, larger size of stomata and pollen grains than diploid (Table 4, Fig. 4). Pentaploid plant, however, was somewhat more dwarf, produced more tillers and panicles than tetraploid, and had a peculiar type of root system as

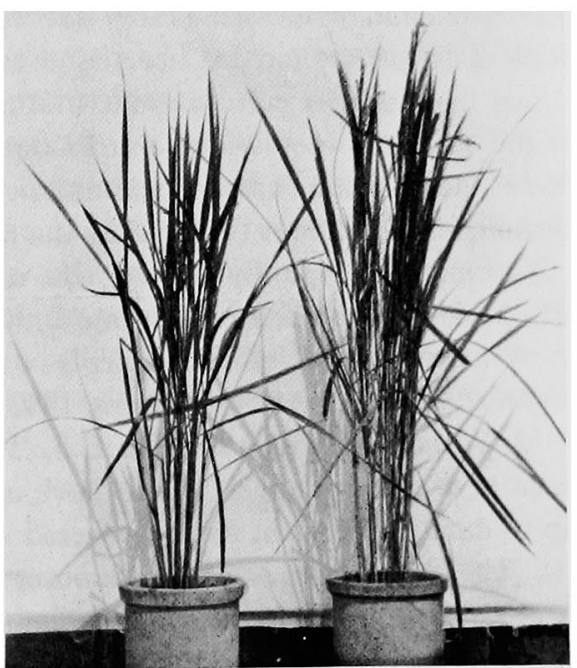

Fig. 4. Grass-types of $2 X$ (right) and $5 X$ (left) plants. 
Table 2. Variation of the number of anthers in a floret of $5 X$ plant

\begin{tabular}{|c|c|c|c|c|c|c|c|c|c|c|c|c|c|c|}
\hline $\begin{array}{c}\text { No. of anthers } \\
\text { in a floret }\end{array}$ & 1 & 2 & 3 & 4 & 5 & 6 & $2+(4)$ & $* 3+(3)$ & $4+(2)$ & $5+(1)$ & $0+(5)$ & $1+(4)$ & $3+(2)$ & Total \\
\hline Frequency & 0 & 0 & 2 & 1 & 2 & 8 & 1 & 8 & 12 & 11 & 1 & 1 & 3 & 50 \\
\hline$(\%)$ & 0 & 0 & 4 & 2 & 4 & 16 & 2 & 16 & 24 & 22 & 2 & 2 & 6 & 100 \\
\hline
\end{tabular}

* Numeral in brackets denotes the number of deformed anther.

Table 3. Variation of the number of pollen-germ-pores in $5 X$ plant

\begin{tabular}{c|cccc|c|c}
\hline No. of germ-pore & 1 & 2 & 3 & 4 & Total \\
\hline Frequency observed & 135 & 152 & 22 & 1 & 310 \\
$\%$ & 43.6 & 49.0 & 7.1 & 0.3 & 100 \\
\hline
\end{tabular}

pointed out already by Nishi and Mitsuoka (1969). Even in open conditions, pentaploid plant was completely sterile. When crossed with the pollens of diploid plants, pentaploid set only imperfect seeds having no germinating ability.

\section{Discussion}

Tissue culture in plant has revealed a brilliant prospect for the practical breeding by inducing haploid plants through the culture of pollen grains or anthers containing them. Recently, however, it has been generally accepted that the callus contains a various number of chromosomes in its constituting cells, and therefore, among the recovered plants derived from tissue culture, various types of polyploids and aneuploids can be found.

Nishi and Mitsuoka (1969) succeeded to secure a series of polyploids from haploid to pentaploid by rice tissue culture. Out of these, pentaploid plant obtained from anther culture is the first case of auto-pentaploid in rice. As a result of the meiotic observations carried out on this plant, it was found that its PMCs reveal the extreme chromosome-mosaicism in spite of its RTCs possessing normal chromosome numbers $(2 n=60)$ as the pentaploid.

Somatic polyploidy in root-tips or chromosome-mosaicism showing a lot of aneuploid cells in one and the same anther-locule has been reported by many workers in normal varieties, hybrid progenies or amphidiploids (Hollingshead 1932, Kattermann 1933, Love 1938, O'Mara 1942, Mochizuki 1943, Li and Tu 1947, Sachs 1952, Watanabe et al. 1955, '56 a, b, '58, '60 a, b, Watanabe, 1961, '62 a, b, Morinaga et al. 1965, Lange 1971). Such an example, however, has never been known up to date as the plant itself recovered from callus showed the meiotic instabilities.

The chromosome-mosaicism observed in the present material does not seem to be the property of pentaploid rice plant. The material used here is the plant designated A4 by Nishi and Mitsuoka (1969). Whether the remaining 6 plants except A4 out of 7 pentaploid plants raised by them show such chromosome-mosaicism or not is an interesting problem. 


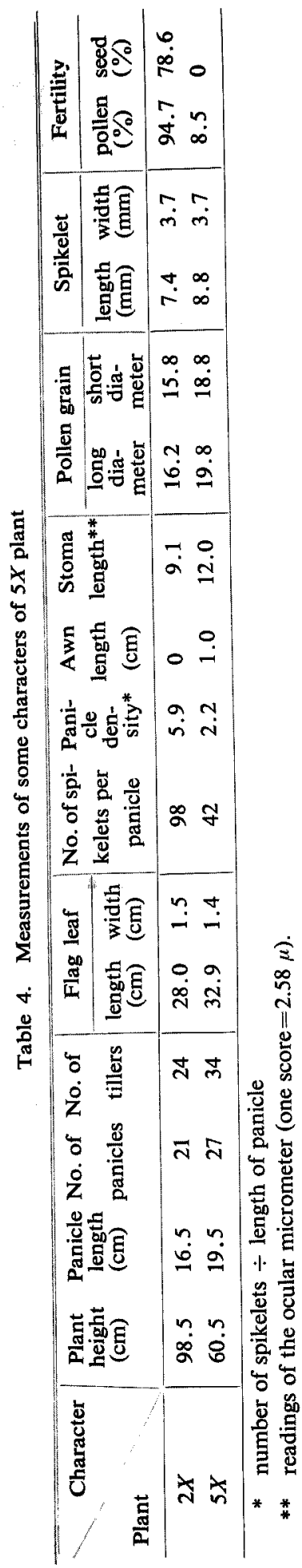

In addition to the chromosome-mosaicism described above, one more interesting feature has been observed in this pentaploid plant. It is the formation of multi-germ-pores on the pollen grain. In rice, it has been determined that one pollen grain possesses one germ-pore. In the present pentaploid rice plant, however, the number of germ-pores per pollen grain varied between 1 and 4, 2 being the mode. In other crops, for example, Beta vulgaris (Nagao and Takahashi 1963), Solanum schreiteri (Kirsanova 1968) or Trifolium spp. (Najcevska and Speckmann 1968), it has been reported that the numbers of germ-pores on the pollen grain varied together with the multiplication of chromosome numbers, while, in rice it has been thought that there is no variation of the numbers of germ-pores accompanied with polyploidy. Perhaps, not only the chromosome-mosaicism but also the variation of the numbers of germ-pores on the pollen grain, may have some associations with the fact that the present pentaploid plant was redifferentiated from the callus.

\section{Summary}

A pentaploid rice plant designated A4 by Nishi and Mitsuoka (1969) showed chromosome-mosaicism in MI of PMCs. When reckoned $2 \mathrm{n}$ numbers from the meiotic chromosome configurations, various aneuploid cells ranging from 33 to 99 were observed in one and the same anther-locule.

Morphologically it resembles tetraploid, but anthesis is quite different. As it is similar to cleistogamy, fertilization has never taken place, resulting in the parthenocarpy. When crossed with the pollens of normal diploids, it set only imperfect seeds having no germinating ability. This plant was characterized by the formation of multi-germ-pores on the pollen grain.

\section{Acknowledgements}

The author wishes to express his hearty thanks to Dr. S. Mitsuoka of Nippon Shinyaku Institute, Kyoto, for his generous supply of this valuable material. 


\section{References}

Hollingshead, L. 1932. The occurrence of unpaired chromosomes in hybrids between varieties of Triticum vulgare. Cytologia 3: 119-141.

Kattermann, G. 1933. Ein Beitrag zur Frage der Dualität der Bestandteile des Bastardkernes. Planta 18: 751-785.

Kirsanova, E. V. 1968. Production of polyploids of some potato species and their use in breeding. Trans. Sci. Res. Inst. Potato Industry No. 5: 50-54.

Lange, W. 1971. Crosses between Hordeum vulgare L. and H. bulbosum L. II. Elimination of chromosomes in hybrid tissues. Euphytica 20: 181-194.

Li, H. W. and Tu, D. S. 1947. Studies on the chromosomal aberrations of the amphidiploid, Triticum Timopheevi and Aegilops bicronis. Bot. Bull. Acad. Sinica 1: 173-186.

Love, R. M. 1938. Somatic variation of chromosome numbers in hybrid wheats. Genetics 23: $517-522$.

Mochizuki, A. 1943. Induced amphidiploid of Aegilops columnaris Zhuk. and Triticum Timopheevi Zhuk. Seiken Zihô 2: 43-54 (in Japansee with English résumé).

Morinaga, T., Watanabe, Y. and Ono, S. 1965. An anomalous $F_{1}$ hybrid of Oryza latifolia Desv. $\times$ O. australiensis Domin. Japan J. Breed. 15: 209 (Abstract in Japanese).

Nagao, S. and Takahashi, M. 1963. Studies in polyploid varieties of sugar beets IX. Tensai Kenkyukai Kenkyu Hôkoku 3: 71-77 (in Japanese).

Najcevska, C. M. and Speckmann, G. J. 1968. Number of chloroplasts and pollen grain pores in diploid and tetraploid varieties of some Trifolium species. Euphytica 17: 357-362.

Nishi, T. and Mitsuoka, S. 1969. Occurrence of various ploidy plants from anther and ovary culture of rice plant. Japan. J. Genet. 44: 341-346.

O'Mara, J. G. 1942. Meiosis in autotetraploid Secale cereale. Bot. Gaz. 104: 563-575.

Sachs, L. 1952. Chromosome mosaics in experimental amphidiploids in the Triticinae. Heredity 6: $157-170$.

Watanabe, Y., Mukade, K. and Saito, S. 1955. Studies on the production of amphidiploids as the sources of resistance to leaf-rust in wheats I. Japan J. Breed. 5: 75-86 (in Japanese with English résumé).

-, - and Kokubun, K. 1956a. Ditto II. Ibid. 6: 23-31 (in Japanese with English résumé).

-, - and Saito, S. 1956b. Ditto III. Ibid. 6: 76-84 (in Japanese with English résumé).

—, - and Kokubun, K. 1958. Ditto IV. Ibid. 7: 169-174 (in Japanese with English résumé).

-, - and - 1960a. Ditto V. Ibid. 10: 169-173 (in Japanese with English résumé).

-, - and - 1960b. Ditto VI. Ibid. 10: 209-214 (in Japanese with English résumé).

- 1961. A new example of chromosome mosaics in Triticinae. Chromosome Information Service No. 2: 10-12.

- 1962a. Chromosome-mosaics observed in a variety of wheat, "Shirahada". Japan. J. Genet. 37: 194-206.

- 1962b. Studies on the cytological instabilities of common wheat. Bull. Tohoku Nat. Agr. Exp. Sta. 23: 69-152 (in Japanese with English résumé). 